\title{
THE DECLINING SHARE OF AGRICULTURAL EMPLOYMENT IN THE PEOPLE'S REPUBLIC OF CHINA: HOW FAST?
}

Jesus Felipe, Connie Dacuycuy, and Matteo Lanzafame

NO. 419

November 2014
ADB ECONOMICS WORKING PAPER SERIES 
ADB Economics Working Paper Series

\section{The Declining Share of Agricultural Employment in the People's Republic of China: How Fast?}

Jesus Felipe, Connie Dacuycuy, and Matteo Lanzafame

\begin{tabular}{l|l} 
No. 419 & 2014
\end{tabular}
Jesus Felipe (jfelipe@adb.org) is an Advisor in the Economics and Research Department of the Asian Development Bank. Connie Dacuycuy is an Assistant Professor at the Ateneo de Manila University. Matteo Lanzafame is an Assistant Professor at the Università degli Studi di Messina, Italy.

We are grateful to Carsten Holz for his comments. 
Asian Development Bank

6 ADB Avenue, Mandaluyong City

1550 Metro Manila, Philippines

www.adb.org

(C) 2014 by Asian Development Bank

November 2014

ISSN 2313-6537 (Print), 2313-6545 (e-ISSN)

Publication Stock No. WPS146985-3

The views expressed in this paper are those of the author and do not necessarily reflect the views and policies of the Asian Development Bank (ADB) or its Board of Governors or the governments they represent.

ADB does not guarantee the accuracy of the data included in this publication and accepts no responsibility for any consequence of their use.

By making any designation of or reference to a particular territory or geographic area, or by using the term "country" in this document, $A D B$ does not intend to make any judgments as to the legal or other status of any territory or area.

Note: In this publication, "\$” refers to US dollars.

The ADB Economics Working Paper Series is a forum for stimulating discussion and eliciting feedback on ongoing and recently completed research and policy studies undertaken by the Asian Development Bank (ADB) staff, consultants, or resource persons. The series deals with key economic and development problems, particularly those facing the Asia and Pacific region; as well as conceptual, analytical, or methodological issues relating to project/program economic analysis, and statistical data and measurement. The series aims to enhance the knowledge on Asia's development and policy challenges; strengthen analytical rigor and quality of ADB's country partnership strategies, and its subregional and country operations; and improve the quality and availability of statistical data and development indicators for monitoring development effectiveness.

The ADB Economics Working Paper Series is a quick-disseminating, informal publication whose titles could subsequently be revised for publication as articles in professional journals or chapters in books. The series is maintained by the Economics and Research Department. 


\section{CONTENTS}

TABLES AND FIGURES

ABSTRACT

V

$\begin{array}{ll}\text { I. INTRODUCTION } & 1\end{array}$

II. EMPIRICALSTRATEGY 6

III. ESTIMATION, DISCUSSION OF THE RESULTS, AND FORECASTING

$\begin{array}{ll}\text { IV. CONCLUSIONS } & 15\end{array}$

$\begin{array}{ll}\text { REFERENCES } & 17\end{array}$ 


\section{TABLES AND FIGURES}

\section{TABLES}

1 Agricultural Employment Share in Total Employment in Selected High-Income Economies, 1870 and 1979

2 Agricultural Employment Shares in Total Employment, Weighted by Population

3 Agricultural Employment Shares in the People's Republic of China; the Republic of Korea; and Taipei,China

$4 \quad$ Unit Root Tests (Dickey-Fuller Generalized Least Squares)

5 Ordinary Least Squares Estimates of Equation (3), 1987-2012

\section{FIGURES}

1 Sectoral Employment 1

2 Sectoral Productivity 2

3 Sector Value Added 6

4 Growth Rate of Agriculture's Employment Share: Actual and Predicted Series, the People's Republic of China

5 Income Elasticity of Agricultural Employment Share 


\begin{abstract}
From 1962 to 2013, the People's Republic of China's (PRC's) agricultural employment share declined from $82 \%$ to $31 \%$. The transfer of workers out of low-productivity agriculture is a fundamental pillar of the PRC's aspirations to progress and eventually become a high-income economy. We hypothesize that the drivers of this decline have been the increase in income per capita, industrial value added, foreign direct investment, and domestic credit. We use an Autoregressive Distributed Lag Model to test the strong exogeneity of the regressors so that we can use it for forecasting. Results indicate that the share of employment in agriculture in the PRC will decline to about $24 \%$ by 2020 , the end of the 13th Five-Year Plan (2016-2020). We also estimate that the PRC's employment share will reach 5\%, the share observed in today's rich economies, by 2042-2048.
\end{abstract}

Keywords: agricultural employment, People's Republic of China, structural transformation

JEL Classification: O13, O53, Q10 


\section{INTRODUCTION}

The purpose of this paper is to model the determinants of the PRC's agricultural employment share and use them to forecast the share up to 2020, the end of the 13th Five-Year Plan (2016-2020). We also ask when the share will become $5 \%$, the same as in most high-income countries today. This exercise is relevant for two related reasons. First, the share of employment in primary agriculture was still 31\% in 2013 and until recently, this sector was the country's largest employer (Figure 1). The PRC's aspirations to become a high-income economy will be reflected in, among other things, a much lower share of agricultural employment of around 3\%-5\%. Second, the Chinese Communist Party (CCP) set an ambitious reform agenda for the 12th Five-Year Plan (2011-2015) and the reforming process is expected to continue during the 13th Five-Year Plan (2016-2020). Planned reforms include increasing the role of markets in resource allocation, modernizing the tax system, relaxing and eventually eliminating the hukou system, and creating an open-door policy (i.e., allowing the international mobility of productive factors).

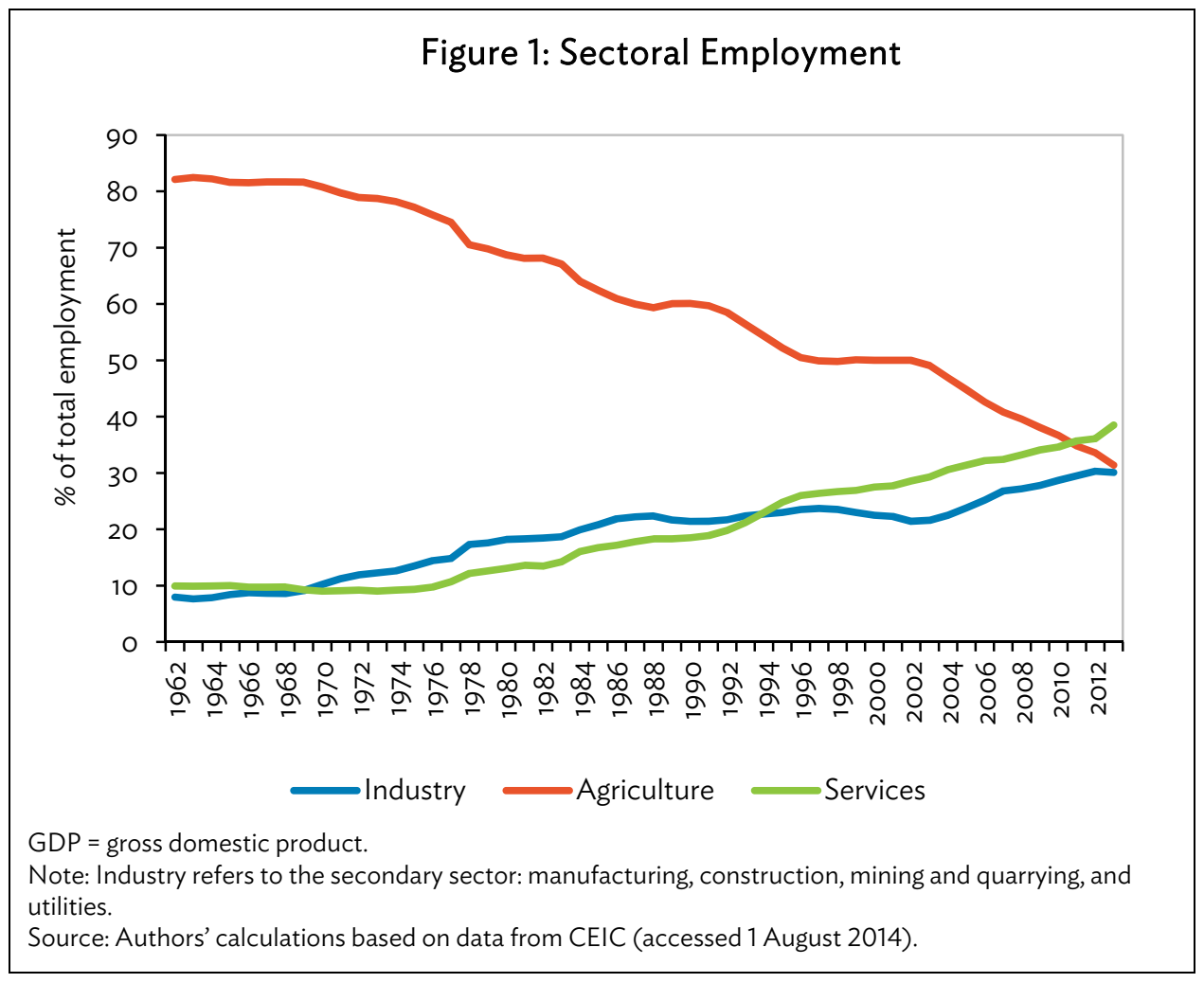

Rapid economic growth has long been viewed by the PRC's policymakers as the most powerful antidote to reform-induced job loss. For an economy that needs about 10 million new jobs each year to keep its urban unemployment rate constant, any growth slowdown is a major concern. This issue is now coming to the fore as the country's growth rate has declined significantly. Will the lower growth rate expected for the near future be sufficiently fast to absorb employment out of agriculture? This question will inevitably have to be addressed if (or when) growth declines persistently below an annual growth rate of $7 \%$ to $7.5 \%$, currently deemed an appropriate growth rate by the PRC's policymakers. 
They are very well aware that this is the key issue moving forward, as reflected in a 2013 speech by Premier Li Keqiang (Hongbin and Xiaoping 2013). ${ }^{1}$

It is hardly surprising, therefore, that employment-related questions are at the center of the reform agenda approved in November 2013 by the 18th National Congress of the CCP. In the spring of 2014, the PRC's top economic planning body gave the first steps to prepare the 13th Five-Year Plan covering 2016-2020, which will decide how to implement the ideas discussed in the 18th National Congress. There is agreement that the PRC needs to change its growth model into one that is less capital- and energy-intensive, yet it needs to continue achieving high growth rates to generate employment and absorb 240 million agricultural workers in the industrial and services sectors.

Labor in traditional agriculture operates at much lower productivity levels than in other sectors. Therefore, and as noted above, the speed at which the transfer of labor out of agriculture takes place is fundamental for the PRC's aspirations to become a high-income economy in the decades ahead. Indeed, as Figure 2 shows, labor productivity in the PRC's agriculture sector is substantially lower than in industry and services.

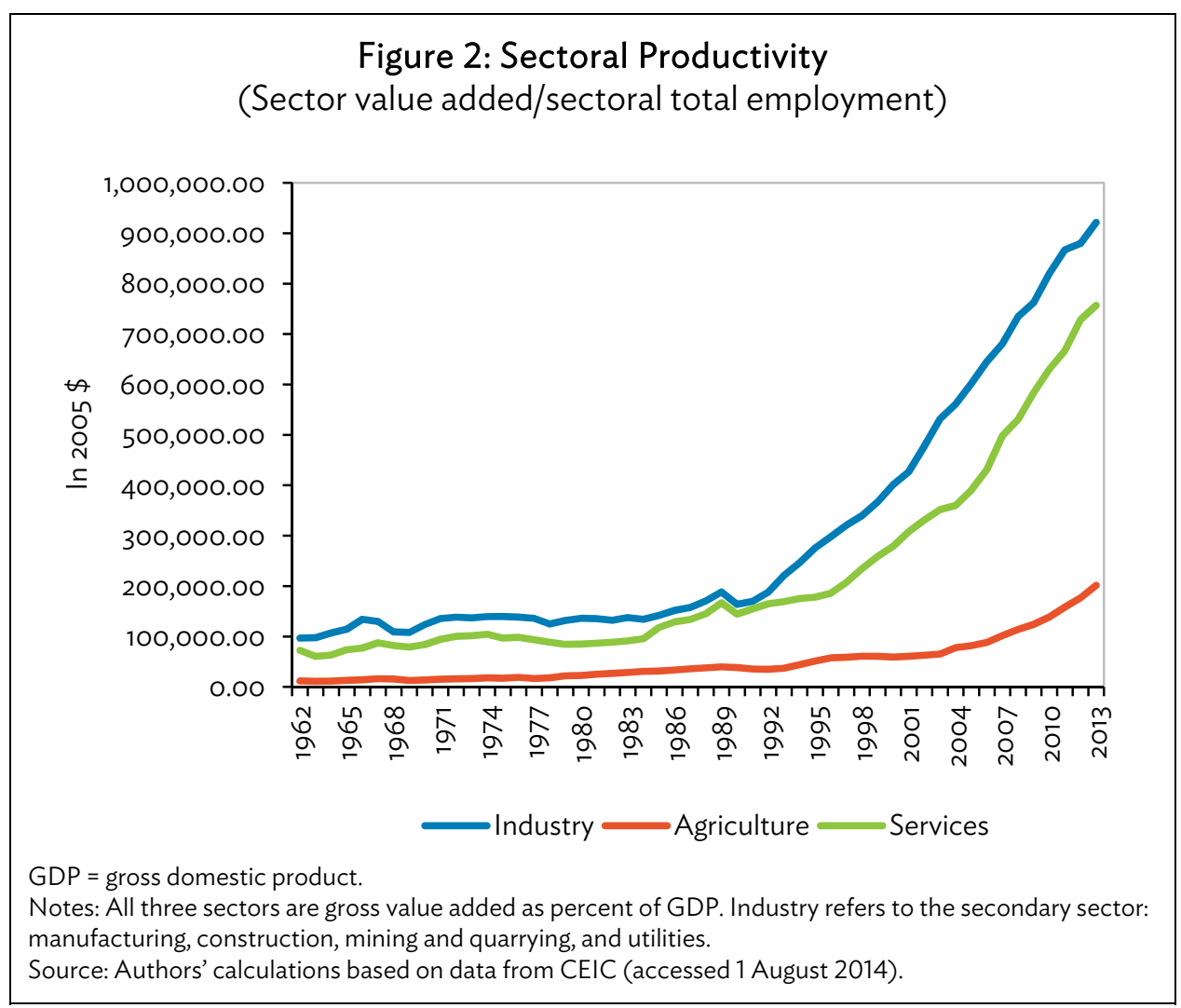

$1 \quad$ In the Premier's words, "We once increased employment by 1 million people for every per cent of GDP growth. Due to the economic restructuring in the past few years and the accelerated development of tertiary industry, every one percent of GDP growth has created 1.3 to 1.5 million job opportunities. The Ministry of Human Resources and Social Security and relevant departments calculated the statistics more than once, on my request. They said that if we are to ensure that 10 million job vacancies are created and urban registered unemployment remains at about 4\%, we need about 7.2\% GDP growth. We need stable growth in order to create employment" (Hongbin and Xiaoping 2013). 
The secular decline in the shares of agricultural value added (in GDP) and employment (in total employment) is a key aspect of economic development (Syrquin 2008). Commonly termed structural transformation, the movement of resources out of the agriculture sector into industry and services, as economies grow richer, is a stylized fact ascribed to forces of demand and supply. On the demand side, demand for food is relatively inelastic. Thus, as income per capita increases, expenditures are diverted from agricultural products to manufactured goods and services. As the country further develops, demand shifts increasingly toward services, and the share of expenditure devoted to manufactured goods stabilizes and then, ultimately, falls in relative terms. As a result, the employment share of manufacturing also stabilizes and eventually falls. On the supply side, the growth of labor productivity in agriculture, due to a whole range of technical innovations, induces a shift of employment out of this sector. The combined effects of demand- and supply-side factors account for the large-scale shift of employment into manufacturing during the industrialization phase of the development process, while the productivity growth differential between manufacturing and services appears to be the key determinant of the subsequent deindustrialization phase.

With a few historical exceptions, structural transformation has been a slow process. According to Maddison (1982, Table 2.2), the shares of employment in agriculture in the Netherlands and the United Kingdom (UK) in the 1700s were 40\% and 60\%, respectively. By 1890, the shares had declined to $33 \%$ and $16 \%$, and by 1979 , to $5.5 \%$ and $2.5 \%$, respectively. Additional data provided by Maddison (1982, Table C5) indicate that between 1870 and 1979, the agricultural employment share in today's rich economies declined between 0.19 percentage points per annum in the UK (whose share was $22.7 \%$ in 1870) and 0.56 percentage points per annum in Japan (whose share was $72.6 \%$ in 1870) (Table 1).

\section{Table 1: Agricultural Employment Share in Total Employment in Selected High-Income Economies, 1870 and 1979}

\begin{tabular}{lcc}
\hline & $\begin{array}{c}\text { Agricultural Employment Share, } \\
1870(\%)\end{array}$ & $\begin{array}{c}\text { Percentage Point Decline, } \\
\text { 1870-1979 (Per annum) }\end{array}$ \\
\hline Australia & 30.0 & 0.22 \\
Austria & 65.0 & 0.50 \\
Belgium & 43.0 & 0.37 \\
Canada & 53.0 & 0.44 \\
Denmark & 51.7 & 0.40 \\
Finland & 71.2 & 0.55 \\
France & 49.2 & 0.37 \\
Germany & 49.5 & 0.40 \\
Italy & 62.0 & 0.44 \\
Japan & 72.6 & 0.56 \\
Netherlands & 37.0 & 0.29 \\
Norway & 53.0 & 0.41 \\
Sweden & 53.9 & 0.44 \\
Switzerland & 49.8 & 0.39 \\
United Kingdom & 22.7 & 0.19 \\
United States & 50.0 & 0.43 \\
\hline
\end{tabular}

Note: The share in 1979 can be obtained by multiplying the percentage point decline by 109 (years) and then subtracting the result from the share in 1870 .

Source: Authors' calculations based on data from Maddison (1982), Table C5. 
Today, most developed economies have agricultural employment shares below 5\%. Table 2 shows that the mean agricultural employment share in the Organisation for Economic Co-operation and Development (OECD) countries was 7\% in the 1980s, $5 \%$ in the 1990 s, and $4 \%$ in the 2000 s. The mean employment share of the Latin American economies exhibits a downward trend as well and was $17.1 \%$ during the last decade. The pace of this decline is slower in the Asian economies, where the mean employment share in the last decade was still about $45 \%$. This is similar to the average for the Sub-Saharan region during the same period.

Table 2: Agricultural Employment Shares in Total Employment, Weighted by Population $(\%)$

\begin{tabular}{lccccccccc}
\hline & \multicolumn{2}{c}{ Asia } & \multicolumn{2}{c}{ Latin American } & \multicolumn{2}{c}{ Countries } & \multicolumn{2}{c}{ OECD } & \multicolumn{2}{c}{ Africa } \\
& Mean & Obs & Mean & Obs & Mean & Obs & \multicolumn{2}{c}{ Mean } & Obs \\
\hline From 1980 to1989 & 60.7 & 76 & 21.6 & 97 & 6.98 & 191 & 44.7 & 11 \\
From 1990 to 1999 & 52.6 & 99 & 17 & 159 & 5.09 & 235 & 68.4 & 29 \\
From 2000 to 2013 & 45.0 & 131 & 17.1 & 200 & 3.92 & 308 & 41.2 & 72 \\
\hline
\end{tabular}

OECD = Organisation for Economic Co-operation and Development.

Notes: Asian economies include Afghanistan, Bangladesh, Bhutan, Cambodia, the People's Republic of China, Fiji, India, Indonesia, Kazakhstan, Kiribati, the Republic of Korea*, Lao People's Democratic Republic, the Marshall Islands, the Federated States of Micronesia, Myanmar, Nauru, Nepal, New Zealand, Pakistan, Palau, Papua New Guinea, the Philippines, Samoa, Solomon Islands, Sri Lanka, Tajikistan, Thailand, Timor-Leste, Turkmenistan, Tuvalu, Uzbekistan, Vanuatu, and Viet Nam. Latin American countries include Argentina, Belize, Bolivia, Brazil, Chile, Colombia, Costa Rica, Ecuador, El Salvador, Guatemala, Honduras, Mexico, Nicaragua, Panama, Paraguay, Peru, Uruguay, and Venezuela. OECD countries are those that became members before 1980. These include Australia, Austria, Belgium, Canada, Denmark, Finland, France, Germany, Greece, Iceland, Ireland, Italy, Japan, Luxembourg, Netherlands, New Zealand, Norway, Poland **, Portugal, the Republic of Korea $\left.{ }^{*}\right)$, Spain, Sweden, Switzerland, the United Kingdom, and the United States. Sub-Saharan Africa includes Angola, Benin, Botswana, Burkina, Faso, Burundi, Cameroon, Central African Republic, Chad, Union of the Comoros, Democratic Republic of the Congo, Republic of the Congo, Cote d'Ivoire, Djibouti, Equatorial Guinea, Eritrea, Ethiopia, Gabon, Gambia, Ghana, Guinea, Guinea-Bissau, Kenya, Lesotho, Liberia, Madagascar, Malawi, Mali, Mauritania, Mauritius, Mozambique, Namibia, Niger, Nigeria, Reunion, Rwanda, Sao Tome and Principe, Senegal, Seychelles, Sierra Leone, Somalia, South Africa, Sudan, Swaziland, Tanzania, Togo, Uganda, Zambia, and Zimbabwe. * The Republic of Korea is included in Asia before 1996 but under OECD afterwards. ${ }^{*}$ Poland is included under OECD from 1996 onwards.

Source: Authors' calculations based on data from the World Bank, World Development Indicators online database (accessed 24 June 2014).

Recently, some Asian economies have been observed to embark on a comparable pattern of labor moving out of agriculture (Holz 2008). Table 3 shows the employment shares in the PRC; the Republic of Korea; and Taipei,China from 1962 to 2013. The percentage point declines during this 50year period are much faster than those registered by the advanced economies between 1870 and 1979 (Table 1). It is worth noting that the shares of the Asian economies in 1962 were significantly higher than those of most advanced economies in 1870. The shares of the Republic of Korea and Taipei,China in 1975 were about the same as those observed in many of the advanced economies in 1870, while the PRC's share in that year was about the same as those seen in Finland or Japan. 


\section{Table 3: Agricultural Employment Shares in the People's Republic of China; the Republic of Korea; and Taipei,China}

$(\%)$

\begin{tabular}{lccc}
\hline & PRC & Republic of & Korea \\
\hline 1962 & 82 & 69 & Taipei,China \\
1975 & 77 & 46 & 30 \\
1990 & 60 & 18 & 13 \\
2000 & 50 & 11 & 8 \\
2013 & 31 & 6 & 5 \\
Percentage point decline per annum & 1 & 1.23 & 0.88 \\
\hline
\end{tabular}

PRC = People's Republic of China.

Sources: The share of Taipei,China in 1962 is obtained as the ratio of agricultural employment (taken from USDA-ERS) to total employment (taken from Penn World Table Version 8.0). The share of the Republic of Korea in 1962 is taken from Fan-Yi (1994). Authors' calculations based on data from ADB's Statistical Database System (accessed 1 October 2014).

In 1962, Taipei,China had the smallest share of the three economies, but by 2013 , the Republic of Korea had caught up, the result of a faster decline of 1.23 percentage points per annum. From 1962 to 2013 , the PRC's agricultural employment share declined from $82 \%$ to $31 \%$. $^{2}$ This corresponds to a decrease of 51 percentage points, which translates into a 1 percentage point decline per year. While the decrease in the share was slow during the 1960s, the reduction during the 1970s, 1980s, and 1990s increased to about 1 percentage point per annum, and it increased to about 2 percentage points per year during the last decade, a very fast pace by historical standards. It is worth noting that the PRC's agricultural employment share in 1975 was much higher than in the Republic of Korea and in Taipei,China; and that still in 2013, it was about the same as in Taipei,China in 1975. At the same time, the share of value added in agriculture declined from 39\% to 10\% during 1962-2013 (Figure 3). This much smaller share indicates that labor productivity in agriculture is lower than the average for the economy as a whole. As labor moves out of this sector and income per capita increases, labor productivity across sectors tends to converge and the differential is progressively reduced.

2 Rawski and Mead (1998) argue that official figures from the PRC overestimate significantly the country's employment in agriculture. According to their estimates, the overcount between 1979 and 1993 was well over 50 million each year, reaching over 100 million in the last years (Table 6, last two columns). We have checked these numbers with other country experts and concluded that the official figures, while not perfect, cannot be as incorrect as Rawski and Meade argue. Moreover, we have estimated that if the number of workers in agriculture in the 1990s were 100 million less than official figures indicate, then the share of employment in agriculture was much lower in 1993, about 41\%-45\%, as opposed to $56.5 \%$ (official figures). If we apply the same decline shown by the official figures from 1993 to 2003 , about 25 percentage points, the share today would be $16 \%-20 \%$. This is very counterintuitive, especially when the share of employment in agriculture in countries like Indonesia, the Philippines, or Thailand is still slightly above $30 \%$. 


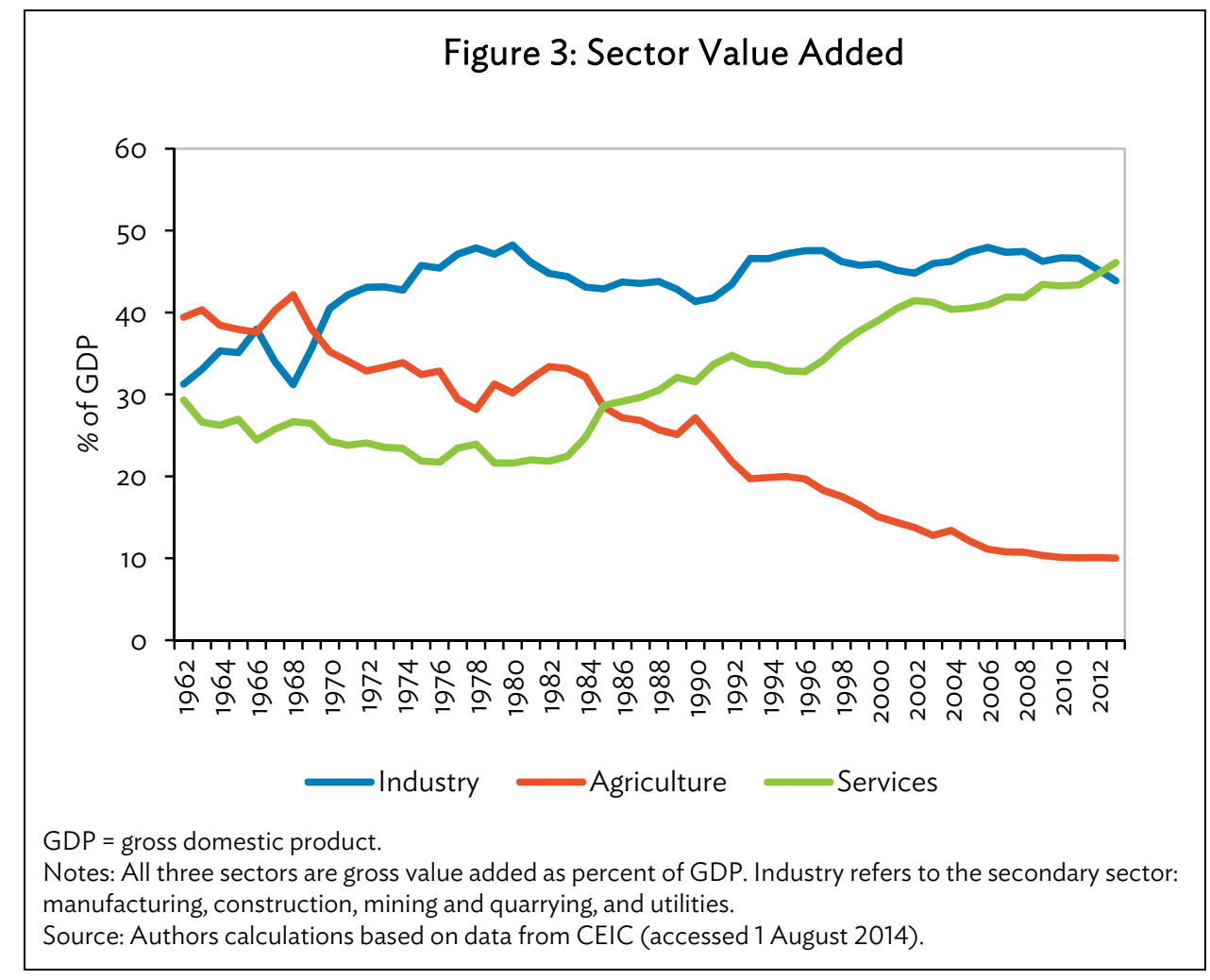

The remainder of the paper is structured as follows. Section II discusses the empirical strategy. Section III shows the estimation results, the strong exogeneity tests, and the forecasts. Finally, Section IV provides the summary and conclusions.

\section{EMPIRICAL STRATEGY}

Given the declining trend that characterizes the PRC's employment share in agriculture since the 1960 s and the historical experiences discussed in the introduction, it is safe to argue that, as the PRC develops, the share of employment in agriculture will not decline in the coming decades faster than it did in the past, that is, at about 1 percentage point per annum. This gives an idea of the expected speed of decline and it would be straightforward, by simple extrapolation, to generate a sensible estimate of how much smaller the share will be in the next few years. The objective of this paper, however, is to investigate the determinants of the declining trajectory of the PRC's agricultural employment share. Specifically, we focus on the role played by changes in GDP per capita, the share of industrial (secondary sector) gross value added in GDP, the share in GDP of net foreign direct investment inflows (FDI), and the share in GDP of credit to the private sector. ${ }^{3}$

We use an error correction model (ECM) to analyze both the short- and long-run dynamics of the employment share in agriculture. We start from an Autoregressive Distributed Lag (ARDL) representation as follows (with variables in natural logarithms):

3 Other variables included in the initial search for the most appropriate model specification were: the real capital stock per worker, number of tertiary students to population ratio, arable land as a percentage of land area, and value added in services as a percentage of GDP. However, either the signs of these variables did not conform to a priori expectations, or they turned out to be statistically insignificant and were therefore excluded from the model. 


$$
\begin{aligned}
& \text { agriemp }_{t}=c+\omega \text { trend }+\sum_{i=0}^{n} \alpha_{i} \text { agriemp }_{t-i}+\sum_{i=0}^{n} \beta_{i} g d p p c_{t-i}+\sum_{i=0}^{n} \delta_{i} g d p p c s q_{t-i}+\sum_{i=0}^{n} \phi_{i} i n d v a_{t-i} \\
& +\sum_{i=0}^{n} \varphi_{i} f d i_{t-i}+\sum_{i=0}^{n} \eta_{i} \text { credit }_{t-i}+\varepsilon_{t}
\end{aligned}
$$

where agriemp is the agricultural employment share, gdppc is income per capita, indva is industrial value added as a percentage of GDP, fdi is net FDI inflows as a percentage of GDP, credit is domestic credit to the private sector by banks as percent of GDP, and $\varepsilon_{t}$ is a random disturbance term. We also include income per capita squared ( $g d p p c s q$ ) to account for possible nonlinear effects of income per capita. The inclusion of a time trend is an empirical issue that will be discussed below.

As income per capita increases, it is expected that the agricultural employment share declines, a hypothesis consistent with the standard patterns of development and structural change. As mentioned, since the rate of decline associated to income per capita can change over time, the squared term is introduced in the model to capture possible nonlinearities. Likewise, a higher value added in industry as a share of GDP is expected to lead to a lower employment share as workers are drawn into industry. Higher FDI is also expected to lower the agricultural employment share. FDI facilitates technological transfers from advanced economies, which tend to foster, in the long term, the development of the more capital-intensive sectors. As a result, FDI typically brings about faster capital accumulation, technological progress, and productivity growth in industry and, via this channel, can boost the outflow of labor from agriculture. Finally, an increase in domestic credit is expected to decrease the employment share in agriculture because it is likely to encourage private investments into the more productive sectors.

While other methods are available to establish and analyze the possible cointegration among these variables, the ARDL strategy, apart from being easy to implement and interpret, can be used to model a mix of I(0) and I(1) series. This can be done through the bounds test procedure developed by Pesaran, Shin, and Smith (2001), which can be applied regardless of whether the variables are I(0) or I(1). Their procedure yields robust estimates in small samples, and estimates of the long-run coefficients are super consistent in small samples. The test for the existence of a significant long-run relationship is an F-test for the variables in lagged levels. If the (computed) F-statistic is smaller than the lower bound, the null hypothesis of no long-run relationship between the variables cannot be rejected. On the other hand, if it is bigger than the upper bound, then there exists a long-run relationship among the series. Finally, if the F-statistic falls within the range, the test is not conclusive.

Although ARDL estimates have a meaningful interpretation even when the series do not have the same order of integration, the bounds test is no longer valid when some of the series are I(2) or of higher order of integration. Thus, as a preliminary step, we rely on the Dickey-Fuller generalized least squares (DFGLS) test to investigate the order of integration of the series under analysis. The computed DFGLS test statistics, shown in Table 4, indicate that the series are not I(2) and hence, the ARDL approach can be applied. 
Table 4: Unit Root Tests (Dickey-Fuller Generalized Least Squares)

\begin{tabular}{|c|c|c|c|c|c|}
\hline & \multicolumn{2}{|c|}{ Log Levels } & \multicolumn{2}{|c|}{ First Differenced } & \multirow[b]{2}{*}{$\begin{array}{c}\text { Order of } \\
\text { Integration }\end{array}$} \\
\hline & $\begin{array}{c}\text { DFGLS Test } \\
\text { Statistic }\end{array}$ & $\begin{array}{c}\text { Schwarz } \\
\text { Criterion } \\
\text { Lag }\end{array}$ & $\begin{array}{c}\text { DFGLS Test } \\
\text { Statistic }\end{array}$ & $\begin{array}{c}\text { Schwarz } \\
\text { Criterion Lag }\end{array}$ & \\
\hline \multicolumn{6}{|l|}{ Without deterministic trend } \\
\hline Agricultural employment share & 0.29 & 1 & $-2.74^{*}$ & 2 & $I(1)$ \\
\hline GDP per capita & -0.22 & 3 & $-2.55^{*}$ & 3 & $I(1)$ \\
\hline Industry value added & -2.01 & 1 & $-2.82^{*}$ & 1 & $I(1)$ \\
\hline Foreign direct investment & -1.29 & 1 & $-3.97^{*}$ & 1 & $I(1)$ \\
\hline Domestic credit & -0.14 & 1 & $-2.92^{*}$ & 1 & $\mathrm{I}(1)$ \\
\hline \multicolumn{6}{|l|}{ With deterministic trend } \\
\hline Agricultural employment share & -1.28 & 1 & $-3.39^{*}$ & 2 & $I(1)$ \\
\hline GDP per capita & $-3.50^{*}$ & 3 & $-3.00^{*}$ & 3 & $\mathrm{I}(0)$ \\
\hline Industry value added & -2.34 & 1 & $-3.17^{*}$ & 1 & $\mathrm{I}(1)$ \\
\hline Foreign direct investment & -2.15 & 1 & $-4.40^{*}$ & 1 & $I(1)$ \\
\hline Domestic credit & -2.49 & 1 & $-4.22^{*}$ & 1 & $I(1)$ \\
\hline
\end{tabular}

DFGLS = Dickey-Fuller generalized least squares, GDP = gross domestic product.

Note: ${ }^{*}$ Null hypothesis of unit root is rejected at the $5 \%$ level.

Source: Authors' calculations.

Before carrying out the estimation of the model, however, two additional issues must be dealt with. The first is the selection of the lag order for the variables in the model, which was carried out with a general-to-specific procedure, starting with a maximum lag order of 4 to take into account the length of the series available. The model specification selected as the most appropriate includes one lag of the dependent variable and two lags for the other regressors. The second issue relates to the inclusion or exclusion of a deterministic time trend. Regression estimates of the ARDL model with and without a deterministic trend were compared and the results indicated that the trend is not statistically significant. Moreover, excluding the trend from the model did not lead to relevant changes in the magnitude of the coefficients, or to changes in the signs and significance of the individual regressors. ${ }^{4}$ Thus, the no-trend specification was chosen as the most appropriate. Therefore, the model we estimate is the following $\operatorname{ARDL}(1,2 ; 5)$ :

$$
\begin{aligned}
& \text { agriemp }_{t}=c+\alpha_{1} \text { agriemp }_{t-1}+\sum_{i=0}^{2} \beta_{i} \text { gdppc }_{t-i}+\sum_{i=0}^{2} \delta_{i} \text { gdppcsq }_{t-i}+\sum_{i=0}^{2} \phi_{i} \text { indva }_{t-i}+\sum_{i=0}^{2} \varphi_{i} f d i_{t-i} \\
& +\sum_{i=0}^{2} \eta_{i} \text { credit }_{t-i}+\varepsilon_{t}
\end{aligned}
$$

where 1 is the number of lags of the dependent variable, 2 is the number of lags of the regressors, 5 is the number of regressors, and the variables are as defined before.

4 Results are not shown, but they are available from the authors upon request. 
For estimation purposes, and following Bårdsen (1989), equation (2) can be written in growth rates (denoted by $\triangle$ ) as follows:

$$
\begin{aligned}
& \text { agriemp }_{t}=c+\beta_{0} \Delta g d p p c_{t}+\beta_{2} \Delta g d p p c_{t-1}+\delta_{0} \Delta g d p p c s q_{t}+\delta_{2} \Delta g d p p c s q_{t-1} \\
& +\phi_{0} \Delta \text { indva }_{t}+\phi_{2} \Delta \text { indva }_{t-1}+\varphi_{0} \Delta f d i_{t}+\varphi_{2} \Delta f d i_{t-1}+\eta_{0} \Delta \text { credit }_{t}+\eta_{2} \Delta \text { credit }_{t-1} \\
& +\alpha^{+} \text {agriemp }_{t-1}+\beta^{+} \text {gdppc }_{t-1}+\delta^{+} \text {gdppcs }_{t-1}+\phi^{+} \text {indva }_{t-1}+\varphi^{+} f d i_{t-1}+\eta^{+} \text {credit }_{t-1}+\varepsilon_{t}
\end{aligned}
$$

where $\alpha^{+}=\left(\alpha_{1}-1\right) ; \beta^{+}=\sum_{i=0}^{2} \beta_{i} ; \delta^{+}=\sum_{i=0}^{2} \delta_{i} ; \phi^{+}=\sum_{i=0}^{2} \phi_{i} ; \varphi^{+}=\sum_{i=0}^{2} \varphi_{i}$ and $\eta^{+}=\sum_{i=0}^{2} \eta_{i}$.

The long-run multipliers are then given by:

$$
\theta_{\text {gdppc }}=\frac{\beta^{+}}{-\alpha^{+}}, \theta_{\text {gdppcsq }}=\frac{\delta^{+}}{-\alpha^{+}}, \theta_{\text {indva }}=\frac{\phi^{+}}{-\alpha^{+}}, \theta_{f d i}=\frac{\varphi^{+}}{-\alpha^{+}}, \text {and } \theta_{\text {credit }}=\frac{\eta^{+}}{-\alpha^{+}}
$$

This parameterization embodies the ECM given by:

$$
\begin{aligned}
& \Delta \text { agriemp }{ }_{t}=c+\beta_{0} \Delta \text { gdppc }_{t}+\beta_{2} \Delta \text { gdppc }_{t-1}+\delta_{0} \Delta \text { gdppcs }_{t}+\delta_{2} \Delta \text { gdppcs }_{t-1} \\
& +\phi_{0} \Delta \text { indva }_{t}+\phi_{2} \Delta \text { indva }_{t-1}+\varphi_{0} \Delta \text { fdi }_{t}+\varphi_{2} \Delta \text { fdi }_{t-1}+\eta_{0} \Delta \text { credit }_{t}+\eta_{2} \Delta \text { credit }_{t-1} \\
& +\alpha^{+} \text {ECT }_{t-1}+\varepsilon_{t}
\end{aligned}
$$

where the speed of adjustment to the steady state is given by $\alpha^{+}$and dynamic stability requires $-1<\alpha^{+}<0$. The error correction term (ECT) is given by:

$$
\begin{aligned}
& E C T_{t-1}=\text { agriemp }_{t-1}-\theta_{g d p p c} g d p p c_{t-1}-\theta_{g d p p c s q} g d p p c s q_{t-1}-\theta_{\text {indva }} \text { indva }_{t-1}-\theta_{f d i} f d i_{t-1} \\
& -\theta_{\text {credit }} \text { credit }_{t-1}
\end{aligned}
$$

\section{ESTIMATION, DISCUSSION OF THE RESULTS, AND FORECASTING}

Equation (3) was estimated by OLS and the results are presented in Table 5. Specifically, the table reports: the regression coefficients; the Durbin's alternative test for autocorrelation, which indicates that the null hypothesis of no autocorrelation cannot be rejected; Pesaran, Shin, and Smith's (2001) cointegration test; the predictive-failure test, which indicates that the second period observations fall within the prediction confidence interval of the first period observations; and the long-run or steadystate solution derived from expression (4). The model's linear prediction of $\Delta a g r i e m p$ as well as the actual series, are shown in Figure 4. 


\section{Table 5: Ordinary Least Squares Estimates of Equation (3), 1987-2012 Dependent Variable is $\Delta$ agriemp}

\begin{tabular}{|c|c|c|}
\hline & Estimates & Standard Error \\
\hline$\Delta g d p p c$ & $3.4108^{* * *}$ & $(0.8324)$ \\
\hline$\Delta g d p p c_{t-1}$ & 0.4326 & $(1.1754)$ \\
\hline$\Delta g d p p c s q$ & $-0.2324^{* * *}$ & $(0.0617)$ \\
\hline$\Delta g d p p c s q_{t-1}$ & -0.0143 & $(0.0924)$ \\
\hline$\Delta i n d v a$ & $-0.4561^{* * *}$ & $(0.1184)$ \\
\hline$\Delta i n d v a_{t-1}$ & -0.1458 & $(0.1359)$ \\
\hline$\Delta f d i$ & -0.0171 & $(0.0106)$ \\
\hline$\Delta f d i_{t-1}$ & $0.0285^{* *}$ & $(0.0092)$ \\
\hline$\Delta$ credit & -0.0305 & $(0.0436)$ \\
\hline$\Delta$ credit $_{t-1}$ & $0.0603^{* *}$ & $(0.0264)$ \\
\hline agriemp $_{t-1}$ & $-0.6448^{* * *}$ & $(0.1675)$ \\
\hline$g d p p c_{t-1}$ & $1.7096^{* * *}$ & $(0.3406)$ \\
\hline$g d p p c s q_{t-1}$ & $-0.1268^{* * *}$ & $(0.0250)$ \\
\hline$i_{n d v} a_{t-1}$ & $-0.7628^{* * *}$ & $(0.2179)$ \\
\hline$f d i_{t-1}$ & $-0.0433^{* * *}$ & $(0.0092)$ \\
\hline credit $_{t-1}$ & -0.0796 & $(0.0615)$ \\
\hline constant & 0.0813 & $(0.7047)$ \\
\hline$R^{2}$ & 0.97 & \\
\hline No. of observations & 26 & \\
\hline \multicolumn{3}{|c|}{$\begin{array}{r}\text { Durbin's alternative test for serial autocorrelation: } \operatorname{chi} 2=0.475 \\
\text { prob }>\text { chi2 }=0.4906\end{array}$} \\
\hline \multicolumn{3}{|c|}{$\begin{array}{l}\text { Cointegration test: Ho: } \alpha^{+}=\beta^{+}=\delta^{+}=\phi^{+}=\varphi^{+}=\eta^{+}=0 \\
\mathrm{~F}(6,9)=8.60\end{array}$} \\
\hline \multicolumn{3}{|c|}{$\begin{array}{l}\text { Long-run equilibrium coefficients (based on the estimates above and equation (4)): } \\
\text { agriemp }=2.6513 g d p p c * * *-0.1966 g d p p c s q * * *-1.1829 \text { ind } v a * *-0.1234 \text { credit }-0.0671 \text { fdi } * * * 0.1261\end{array}$} \\
\hline$(0.3856)$ & $(0.0971)$ & $(0.0120)$ \\
\hline
\end{tabular}

Notes: ${ }^{*}{ }^{* *}{ }^{* * *}$ denotes significance at $10 / 5 / 1 \%$ level. Computed F-statistic in the cointegration test is compared with the critical values in table $\mathrm{Cl}$ (iii)-unrestricted intercept and no trend-in Pesaran, Shin, and Smith (2001). Figures in parenthesis under each long-run equilibrium value are the corresponding standard errors.

Sources: Agricultural employment share in total employment and the share of industrial (secondary sector) gross value added in GDP are taken from CEIC (accessed 1 August 2014); GDP per capita in constant 2005 \$, net inflows of FDI as percent of GDP, and domestic credit to the private sector as percent of GDP are taken from the World Bank's World Development Indicators online database (accessed 24 June 2014). 


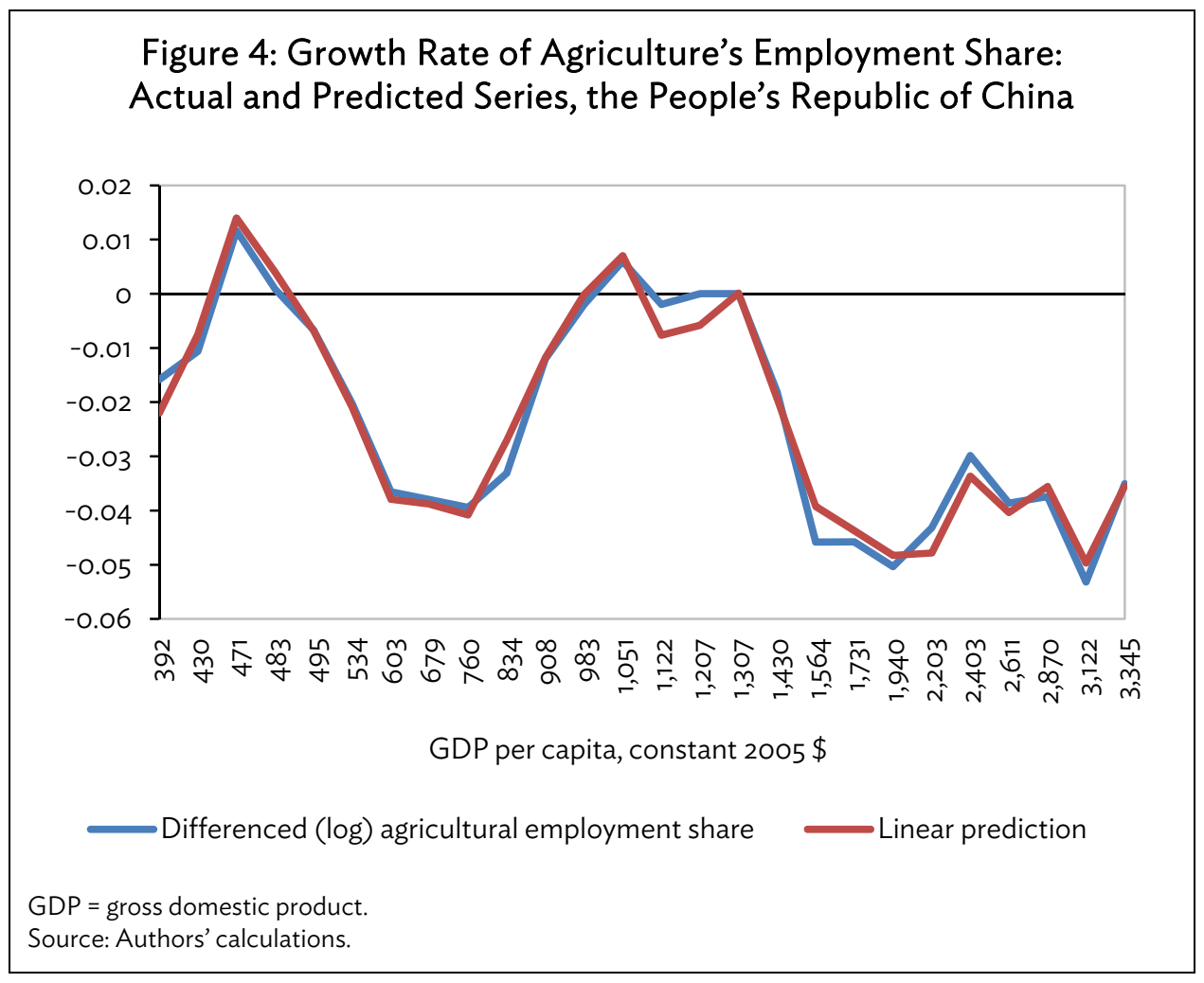

To determine if a long-run relationship exists between the variables, we adopt Pesaran, Shin, and Smith (2001) bounds test procedure within the context of our ARDL model. As noted above, this is an F-test for the null hypothesis that $\alpha^{+}=\beta^{+}=\delta^{+}=\phi^{+}=\varphi^{+}=\eta^{+}=0$. In other words, it is a test for the absence of a stationary long-run relationship between the variables embodied in the ECM. The resulting F-statistic based on the OLS estimates of equation (3) is 8.6. The relevant bands of critical values for a model with five regressors, an unrestricted intercept and no determinist trend are: $2.62-$ 3.79 at the $5 \%$ level of significance, and 3.41-4.68 at the $1 \%$ level of significance. Since the computed F-statistic is above the critical band, the null hypothesis is rejected. There is, therefore, a long-run relationship between the share of employment in agriculture, income per capita, income per capita squared, industrial value added, FDI, and domestic credit. $^{5}$

Results indicate that a $1 \%$ increase in industrial value added leads to a decrease in the share of employment in agriculture by $0.60 \%$ in the short run, while it leads to a long-run decrease in the share

5 We also used Johansen's cointegration test. Results are not identical to those discussed above but do support, at least partially, our analysis. Results suggest that there are at least two cointegrating vectors. The employment share cointegrating vector enters the employment share equation with a smaller adjustment coefficient than the one estimated in Table 5, while it does not appear to enter the income per capita and industrial value added equations (i.e., the adjustment coefficients are zero, a necessary condition for these variables to be weakly exogenous in a conditional employment share equation). However, the adjustment coefficients of this vector in the domestic credit and FDI equations are implausibly large. The values of the adjustment coefficients of the other cointegrating vectors are extremely difficult to interpret (some of them have implausible values). Finally, if we impose the exactly identifying restriction and normalize the first cointegrating vector in the employment share regression with respect to the employment share, the values are very similar to those shown at the bottom of Table 6 (long-run equilibrium coefficients). Given these results, we concluded that modeling the agriculture's employment share conditioning on the other variables is a sensible strategy, assuming that these other variables are weakly exogenous for the parameters of the employment share equation. This is discussed below. 
of $1.18 \%$. The short-run effect of net FDI inflows is an increase in agriculture's employment share by a very small $0.01 \%$, while it leads to a decrease in the share by $0.07 \%$ in the long run. Credit to the private sector increases agriculture's employment by $0.03 \%$ in the short-run, while it leads to a decrease in the employment share by $0.12 \%$ in the long-run. The speed of adjustment toward the long-run equilibrium is relatively fast: $64.5 \%$ of the gap with the steady state is closed each year.

Finally, Figure 5 shows the income elasticity of the agricultural employment share with respect to income per capita. As hypothesized, it declines as income per capita increases, although not at a constant rate (note that the long-run estimates of both income per capita and its square are significant). Results indicate that the income elasticity of the share is positive for very low income levels, and increases with income per capita until it reaches $\$ 846$ - at this income level, the elasticity becomes equal to zero. Beyond the $\$ 846$ threshold, the income elasticity of the agricultural employment share becomes negative, so that further increases in income per capita lead to (gradually smaller) decreases in the share.

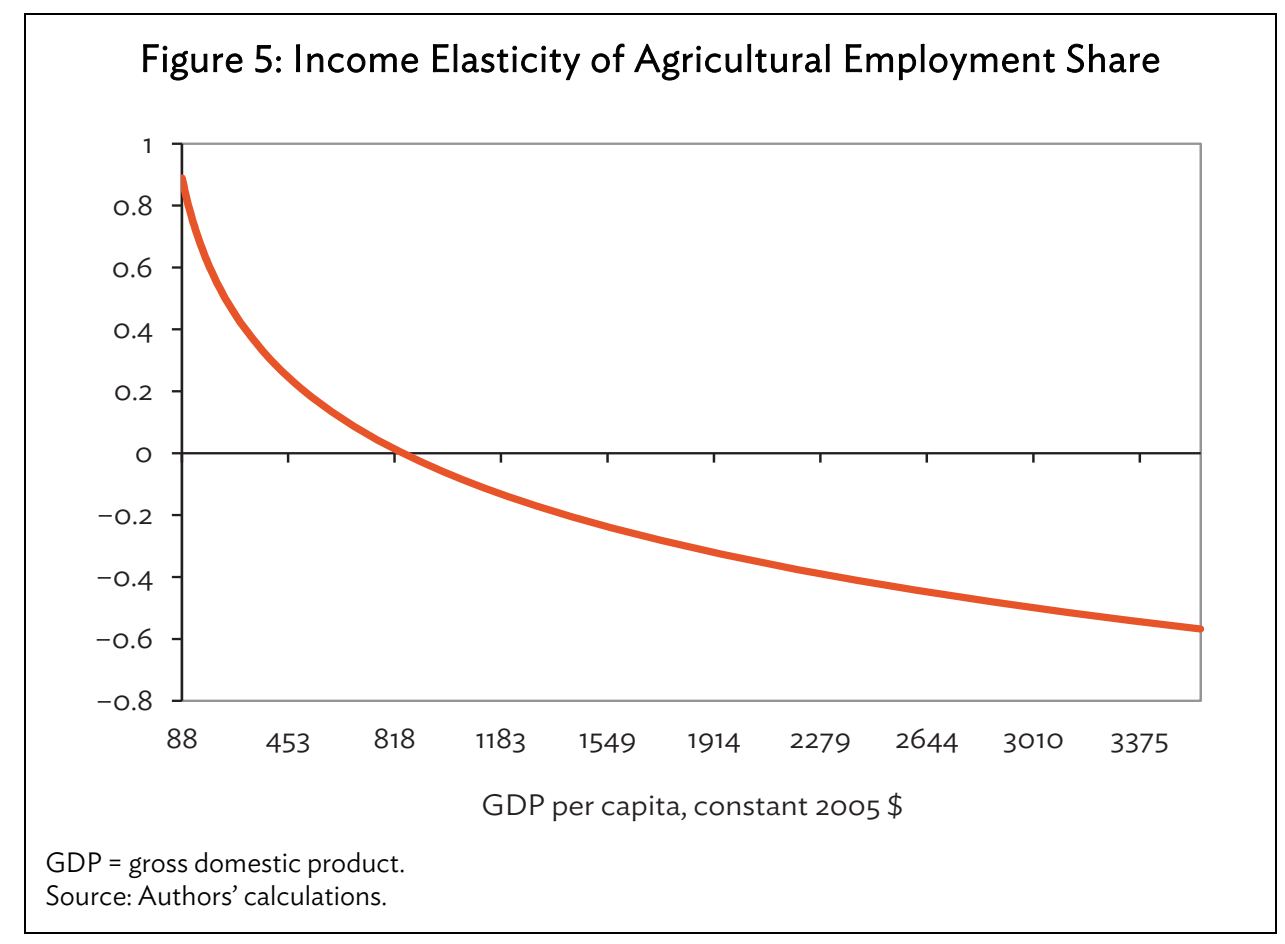

\section{Strong exogeneity analysis and forecasting}

Engle, Hendry, and Richard (1983) introduced three notions of exogeneity, namely, weak exogeneity for hypothesis testing, strong exogeneity for forecasting, and super exogeneity for policy analysis. These concepts denote properties of a variable with respect to the parameters of interest. Here we are interested in the concept of strong exogeneity. A variable $z_{t}$ is said to be strongly exogenous with respect to another variable $y_{t}$ (left hand-side variable in the conditional model) if $z_{t}$ is weakly exogenous for the parameters of interest and if past values of $y_{t}$ do not Granger-cause $z_{t}$. Therefore, testing for strong exogeneity consists of testing first for weak exogeneity, and then for Granger- 
causality. ${ }^{6}$ Moreover, since our series are cointegrated, one or more terms on the right-hand side must be Granger-caused by the lagged error correction term, which is itself a function of the lagged elements on the right-hand side of the model (Granger 1988).

To implement these tests, we follow Ericsson and Irons (1994) and Urbain (1993). While we are more interested in the long-run relationships between the variables under consideration, for completeness, we analyze both the short- and long-run parameters in the model. Weak exogeneity requires: (i) the standard orthogonality condition and (ii) the absence of the cointegrating vector in the remaining equations. The two can be tested jointly by estimating unrestricted reduced ECMs for $\Delta g d p p c, \Delta g d p p c s q, \Delta i n d v a, \Delta f d i$, and $\Delta c r e d i t$ (i.e., the marginal models), to which we add the fitted residuals of the ECM in Table (5) and the one-period lagged error correction term. ${ }^{7}$ Hypotheses (i) and (ii) can be verified by testing whether the last two additional terms are jointly equal to zero. Results are shown in Table 6.

Table 6: Statistics for Weak and Strong Exogeneity Tests

\begin{tabular}{|c|c|c|}
\hline \multicolumn{3}{|c|}{ Weak Exogeneity Test } \\
\hline \multicolumn{2}{|c|}{ Differenced gdppc } & F-Weak \\
\hline$E C T_{t-1}$ & Residual & Ho: $E C T_{t-1}=$ residual $=0$ \\
\hline $0.27^{* *}$ & 0.00 & $\begin{array}{l}F(2, \quad 23)=3.33 \\
\text { Prob }>F=0.05\end{array}$ \\
\hline \multicolumn{3}{|c|}{ Differenced gdppcsq } \\
\hline$E C T_{t-1}$ & Residual & Ho: $E C T_{t-1}=$ residual $=0$ \\
\hline 2.33 & 0.00 & $\begin{array}{l}F(2, \quad 23)=0.90 \\
\text { Prob }>F=0.42\end{array}$ \\
\hline \multicolumn{3}{|c|}{ Differenced indva } \\
\hline$E C T_{t-1}$ & Residual & Ho: $E C T_{t-1}=$ residual $=0$ \\
\hline 0.051 & 0.00 & $\begin{array}{l}F(2, \quad 23)=0.01 \\
\text { Prob }>F=0.99\end{array}$ \\
\hline \multicolumn{3}{|c|}{ Differenced fdi } \\
\hline$E C T_{t-1}$ & Residual & Ho: $E C T_{t-1}=$ residual $=0$ \\
\hline 0.25 & 0.00 & $\begin{array}{l}F(2, \quad 23)=0.01 \\
\text { Prob }>F=0.99\end{array}$ \\
\hline \multicolumn{3}{|c|}{ Differenced credit } \\
\hline$E C T_{t-1}$ & Residual & Ho: $E C T_{t-1}=$ residual $=0$ \\
\hline$-0.56^{*}$ & 0.00 & $\begin{array}{l}F(2,23)=1.58 \\
\text { Prob }>F=0.23\end{array}$ \\
\hline
\end{tabular}

$6 \quad$ A variable is said to be weakly exogenous for the parameters of interest if the latter are only functions of the parameters of interest in the conditional model, and if the parameters of the conditional and marginal models are variation-free (i.e., there are no cross-restrictions between conditional and marginal models). We already noted above that the employment share error correction term does not appear to enter the other equations (see footnote 6, where we refer to Johansen's cointegration test). Strong exogeneity also requires that past values of the left-hand side variable of the conditional equation (the employment share in our case) do not Granger-cause the other variables.

7 Strictly speaking, the residuals we add are those from equation (5), that is, equation (3) (in Table 5) re-estimated imposing the error correction term. 
Table 6 continued

\begin{tabular}{lll}
\hline Strong Exogeneity Test & $\begin{array}{l}\mathrm{F} \text {-strong } \\
\text { Ho: Differenced agriemp } \mathrm{t}_{\mathrm{t}-1}=\end{array}$ & Ho: $E C T_{\mathrm{t}-1}=0$ \\
& $\begin{array}{l}\text { Differenced } \text { agriemp }_{\mathrm{t}-2} \\
\text { Differenced gdppc }\end{array}$ & $\mathrm{F}(1,22)=2.29 ;$ Prob $>\mathrm{F}=0.10>|\mathrm{t}|=0.20$ \\
Differenced gdppcsq & $\mathrm{F}(1,22)=3.07 ; \operatorname{Prob}>\mathrm{F}=0.04$ & $\operatorname{Prob}>|\mathrm{t}|=0.54$ \\
Differenced indva & $\mathrm{F}(1,22)=1.15 ;$ Prob $>\mathrm{F}=0.30$ & Prob $>|\mathrm{t}|=0.17$ \\
Differenced fdi & $\mathrm{F}(1,22)=1.20 ;$ Prob $>\mathrm{F}=0.35$ & Prob $>|\mathrm{t}|=0.28$ \\
Differenced credit & $\mathrm{F}(1,22)=2.26 ;$ Prob $>\mathrm{F}=0.12$ & Prob $>|\mathrm{t}|=0.55$ \\
\hline
\end{tabular}

Note: $\mathrm{ECT}$ is the error correction term calculated as: $E C T=$ agriemp -2.6513 gdppc +0.1966 gdppcsq +1.1829 indva +0.1234 credit +0.0671 fdi Source: Authors' calculations.

The upper part of Table 6 shows the weak exogeneity tests, denoted F-weak. Except in the case of $\Delta g d p p c$, the null hypothesis that the variables are weakly exogenous for the parameters of interest cannot be rejected. The tests for strong exogeneity (Granger causality), shown in the lower part of Table 6, denoted F-strong, indicate that none of the variables are Granger-caused by the error correction term; and that the null is rejected for the past values of the dependent variable only for $\Delta g d p p c$ and $\Delta g d p p c s q$. Overall, these results indicate that our conditional model (equation (3), shown in Table 5) can be used for forecasting.

Finally, we show in Table 7 the forecasts for the PRC's agricultural employment share under different scenarios, designed to capture the speed of its decline. All scenarios assume that GDP per capita grows at 6.5\% per annum from 2013 onward, with an initial GDP per capita (in 2013) of US $\$ 3,583$. Under scenario 1, industrial value added as percent of GDP, FDI as percent of GDP and domestic credit as percent of GDP are assumed to take their 2012 values of $45.27 \%, 3.59 \%$ and $133.69 \%$, respectively. Results indicate that by 2020 , the final year of the 13th Five-Year Plan, the employment share of agriculture in the PRC will be $24 \%$. Our model also implies that this share will be about $18 \%$ by 2025 and will fall down to 5\% in 2044. Scenario 2 assumes that industrial value added, FDI, and domestic credit grow during the forecast period at their 1985-2012 growth rates. Results are virtually identical to those in scenario 1. In scenario 3, industrial value added grows during the forecast period at its 1985-2012 growth rate, while the shares of FDI and domestic credit double. Under these circumstances, the employment share in 2020 (2025) will be 21\% (16\%), and it will reach 5\% in 2042. In scenarios 4 and 5, we show what happens if industrial value added declines to $30 \%$ of GDP during the forecast period. In scenario 4, we further assume that the shares of FDI and credit to the private sector take on the same values as in scenario 2. In this case, the employment share in 2020 (2025) will be $38 \%$ (30\%), and will reach $5 \%$ in 2049 . And in scenario 5, we further assume that, as in scenario 3 , the shares of FDI and credit double. In this case, the employment share in 2020 (2025) will be 34\% (26\%), and it will reach 5\% in 2048. 


\section{Table 7: Forecasts of Agricultural Employment Share, the People's Republic of China}

\begin{tabular}{|c|c|c|c|}
\hline Scenario & $\begin{array}{l}\text { Forecast } \\
\text { Period }\end{array}$ & $\begin{array}{c}\text { Agricultural } \\
\text { Employment } \\
\text { Share (\%) }\end{array}$ & $\begin{array}{c}\text { Agricultural } \\
\text { Employment } \\
\text { Share Will } \\
\text { Become } 5 \% \text { by: }\end{array}$ \\
\hline \multirow{2}{*}{$\begin{array}{l}\text { 1. Industrial value added, FDI, and domestic credit are equal to } \\
\text { their } 2012 \text { values at } 45.27 \%, 3.59 \% \text {, and } 133.69 \% \text {, respectively. }\end{array}$} & 2013-2020 & 24 & \multirow[b]{2}{*}{2044} \\
\hline & 2013-2025 & 18 & \\
\hline \multirow{2}{*}{$\begin{array}{l}\text { 2. Industrial value added, } \mathrm{FDI} \text {, and domestic credit are equal to } \\
45.36 \%, 3.85 \% \text {, and } 137.25 \% \text {, respectively. }\end{array}$} & $2013-2020$ & 23 & \multirow[b]{2}{*}{2044} \\
\hline & 2013-2025 & 18 & \\
\hline \multirow{2}{*}{$\begin{array}{l}\text { 3. Industrial value added is equal to } 45.36 \%{ }^{\mathrm{a}} 2012 \mathrm{FDI} \text { and } \\
\text { domestic credit values double. }\end{array}$} & $2013-2020$ & 21 & \multirow[b]{2}{*}{2042} \\
\hline & 2013-2025 & 16 & \\
\hline \multirow{2}{*}{$\begin{array}{l}\text { 4. Industrial value added declines to } 30 \% \text {. FDI and domestic } \\
\text { credit are equal to } 3.85 \% \text { and } 137.25 \% \text {, respectively. }{ }^{2}\end{array}$} & $2013-2020$ & 38 & \multirow[b]{2}{*}{2049} \\
\hline & 2013-2025 & 30 & \\
\hline \multirow{2}{*}{$\begin{array}{l}\text { 5. Industrial value added declines to } 30 \% \text {. FDI and domestic } \\
\text { credit double. }\end{array}$} & $2013-2020$ & 34 & \multirow[b]{2}{*}{2048} \\
\hline & $2013-2025$ & 26 & \\
\hline
\end{tabular}

$\mathrm{FDI}=$ foreign direct investment.

a Figures are based on the assumption that industrial value added, FDI, and domestic credit grow during the forecast period at their 19852012 growth rates: $0.20 \%, 7.3 \%$, and $2.65 \%$, respectively.

Note: All scenarios assume 6.5\% GDP per capita growth per annum. Initial GDP per capita is \$3,583 in 2013.

Source: Authors' calculations.

Based on these scenarios, it will take about 80 to 87 years (from 1962) for the PRC's employment share to fall down at the level characteristic of an advanced economy today. This means that the pace of this process is likely to be faster in the PRC than it was, on average, in advanced economies in the past. It also suggests that the PRC can be expected to have another three decades during which it will benefit from structural transformation as a source of economic growth.

\section{CONCLUSIONS}

Given the low productivity of the labor employed in agriculture, one key to the PRC's aspirations to become a high-income economy in the coming decades is the decline in the agricultural employment share, still $31.0 \%$ in 2013. This paper has analyzed the drivers of the PRC's agricultural employment share and used them to forecast the share by the end of the 13th Five-Year Plan (2016-2020). We have also forecast the year the employment share will reach $5.0 \%$, approximately the same as in advanced economies today.

We have used an ARDL model to estimate a regression of the employment share in agriculture conditional on income per capita and its square, industrial value added, and the shares of FDI and credit to the private sector in GDP. Results identify the factors that can bring down the agricultural employment share. Some of the variables included are proxies for the reforms outlined in the 12th (and possibly 13th) Five-Year Plans. In particular, the long-run effect of FDI indicates that the proposed intensification of an open-door policy will help the PRC's structural transformation. Results also indicate that domestic credit has the potential to contribute to the decline of agricultural employment. With the enhanced role of markets in resource allocation, financial markets stand to become more 
competitive and efficient investment decisions will alter the composition of sectoral employment in the process. Enhancing markets to better allocate resources, combined with genuine reforms to relax institutional rigidities such as the hukou system, will help increase economic efficiency and accelerate the country's structural transformation.

In addition, industrial value added and income per capita have the biggest long-run effects on the decline of the employment share. These results confirm that the PRC's path to structural transformation follows well-known patterns of development.

Based on our model, it will take about 80-87 years (from 1962) for the PRC to have an agricultural employment share as that in most advanced economies today, about $5 \%$. This is faster than the speed of decline observed for this share in the advanced economies in the past. The PRC's rapid growth since economic reforms started in 1978 has no historical precedent, and its growth of at least $8 \%$ each year is the strongest driver that propelled labor away from agriculture. Given that the effect of income per capita on the employment share is non-linear (through the squared term), the transfer of labor out of agriculture will not be as fast as in earlier periods. 


\section{REFERENCES*}

ADB. Statistical Database System (SDBS). https://sdbs.adb.org/sdbs/index.jsp (accessed 1 October 2014).

Bårdsen, G. 1989. Estimation of Long-Run Coefficients in Error Correction Models. Oxford Bulletin of Economics and Statistics. 51. pp. 345-350.

Elliott, G., T. Rothenberg, and J. Stock. 1996. Efficient Tests for an Autoregressive Unit Root. Econometrica. 64 (4). pp. 813-836.

Engle, R., D. Hendry, and J. Richard. 1983. Exogeneity. Econometrica. 51. pp. 277-304.

Ericsson, N. R. and J. Irons. 1994. Testing Exogeneity. Oxford University Press.

Fan-Yi, W. 1994. Reconsidering Export-Led Growth. In J. Aberbach, D. Dollar, and K. Sokoloff, eds. New York: M. E. Sharpe, Inc.

Granger, C. W. J. 1988. Some Recent Developments in the Concept of Causality. Journal of Econometrics. 39. pp. 199-211.

Holz, C. 2008. China's Economic Growth 1978-2025: What We Know Today About China's Economic Growth Tomorrow. World Development. 36 (10). pp. 1665-1691.

Hongbin, Q., and M. Xiaoping. 2013. From the Horse's Mouth. Full transcript of Premier Li Keqiang's speech delivered at the 16th National Congress of the All-China Federation of Trade Unions. HSBC Global Research. 15 November.

Maddison, A. 1982. Phases of Capitalist Development. New York: Oxford University Press.

Pesaran, M., Y. Shin, and R. Smith R. 2001. Bounds Testing Approaches to the Analysis of Level Relationships. Journal of Applied Economics. 16. pp. 289-326.

Rawski, T., R. W. Mead. 1998. On the Trail of China's Phantom Workers. World Development. 26 (5). pp. 767-781.

Syrquin, M. 2008. Structural Change and Development. In A. K. Dutt and J. Ros, eds. International Handbook of Development Economics. Vol. 1. pp. 48-67. Edward Elgar.

United States Department of Agriculture (USDA). Economic Research Service (ERS). http://www.ers .usda.gov/data-products/agricultural-productivity-in-the-us.aspx

Urbain, J.-P. 1993. Exogeneity in Error Correction Models. Springer-Verlag.

World Bank. World Development Indicators (WDI). http://data.worldbank.org/data-catalog/world -development-indicators (accessed 24 June 2014).

* ADB recognizes China as the People's Republic of China. 


\section{The Declining Share of Agricultural Employment in the People's Republic of China}

How Fast?

The transfer of workers out of low-productivity agriculture is a fundamental pillar of the People's Republic of China's (PRC's) aspirations to progress and eventually become a high-income economy. We show that the share of employment in agriculture will decline to about $24 \%$ by 2020 , the end of the 13 th Five-Year Plan (2016-2020). We also estimate that the PRC's employment share will reach 5\%, the share observed in today's rich economies, by $2042-2048$.

\section{About the Asian Development Bank}

ADB's vision is an Asia and Pacific region free of poverty. Its mission is to help its developing member countries reduce poverty and improve the quality of life of their people. Despite the region's many successes, it remains home to approximately two-thirds of the world's poor: 1.6 billion people who live on less than $\$ 2$ a day, with 733 million struggling on less than $\$ 1.25$ a day. $A D B$ is committed to reducing poverty through inclusive economic growth, environmentally sustainable growth, and regional integration.

Based in Manila, ADB is owned by 67 members, including 48 from the region. Its main instruments for helping its developing member countries are policy dialogue, loans, equity investments, guarantees, grants, and technical assistance. 